
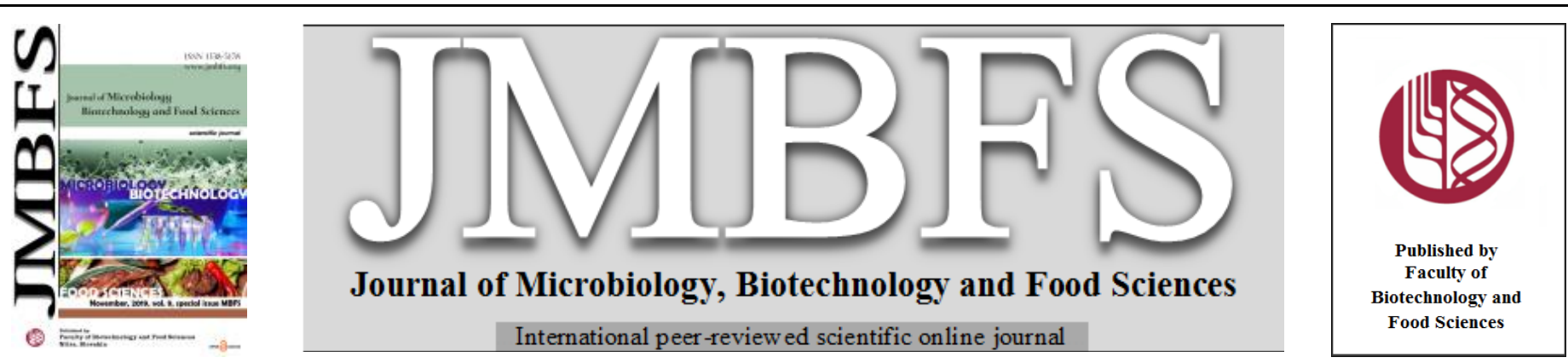

\title{
THE EFFECT OF SEA BUCKTHORN (HIPPOPHAE RHAMNOIDES L.) BERRIES ON PARAMETERS OF QUALITY RAW COOKED MEAT PRODUCT
}

\author{
Marek Bobko*l, Miroslav Kročko ${ }^{1}$, Peter Haščik ${ }^{l}$, Jana Tkáčovál, Ondrej Bučko ${ }^{2}$, Alica Bobková̉, Juraj Čuboñl , Martin Češkovič4, \\ Adriana Pavelkova ${ }^{1}$
}

Address(es): doc. Ing. Marek Bobko, PhD.

${ }^{1}$ Slovak University of Agriculture in Nitra, Department Technology and Quality of Animal Products, Tr. A. Hlinku 2, 94976 Nitra, Slovakia.

${ }^{2}$ Slovak University of Agriculture in Nitra, Department of Plant Products Storage and Processing, Tr. A. Hlinku 2, 94976 Nitra, Slovakia.

${ }^{3}$ Slovak University of Agriculture in Nitra, Department of Food Hygiene and Safety, Tr. A. Hlinku 2, 94976 Nitra, Slovakia.

${ }^{4}$ Food Industry plus s.r.o., Ploské 158, 044 44, Slovakia

*Corresponding author: marek.bobko@uniag.sk

doi: 10.15414/jmbfs.2019.9.special.366-369

\section{ARTICLE INFO}

Received 18. 7. 2019

Revised 13. 9. 2019

Accepted 14. 9. 2019

Published 8. 11. 2019

Regular article open $O$ access

\begin{abstract}
The aim of present study was evaluated chosen quality parameters (oxidative stability, colour, sensory quality) of raw cooked meat product after sea buckthorn application. In the experiment was 5 groups: control group (C) (without addition), P1 (5 ml of sea buckthorn juice per $\mathrm{kg}$ of meat mixture), P2 (10 ml of sea buckthorn juice per kg of meat mixture), P3 ( $0.1 \mathrm{ml}$ of sea buckthorn oil per $\mathrm{kg}$ of meat mixture), $\mathrm{P} 4(0.5 \mathrm{ml}$ of sea buckthorn oil per $\mathrm{kg}$ of meat mixture). The samples were stored under refrigerated conditions at $4 \pm 1{ }^{\circ} \mathrm{C}$ and analysed on $1,4,7$ and 10 days. At the end of storage, we observed higher oxidation stability $(\mathrm{P} \leq 0.05)$ in all experimental groups compared to the $\mathrm{C}$ group. In $\mathrm{C}$ group was recorded the highest production of MDA $\left(0.289 \mathrm{mg} \cdot \mathrm{kg}^{-1}\right)$. From the experimental groups with different additions $(\mathrm{P} \geq 0.05)$ of bio juice and oil, we observed the highest degree of oxidative stability in the $\mathrm{P} 4$ with addition of bio oil in the amount of $0.5 \mathrm{ml}\left(0.229 \mathrm{mg} \cdot \mathrm{kg}^{-1}\right)$ and bio juice with addition of $10 \mathrm{ml}\left(\mathrm{P} 2-0.234 \mathrm{mg} \cdot \mathrm{kg}^{-1}\right)$. A slightly higher degree of oxidative damage was observed with the addition of bio oil in the amount of $0.1 \mathrm{ml}\left(\mathrm{P} 3-0.245 \mathrm{mg} . \mathrm{kg}^{-1}\right)$ and bio juice with the addition of $5 \mathrm{ml}\left(\mathrm{P} 1-0.248 \mathrm{mg} \cdot \mathrm{kg}^{-1}\right)$. We had not found significantly differences $(\mathrm{P}>0.05)$ among all groups at colour parameters evaluation $\left(\mathrm{L}^{*} \mathrm{a}^{*} \mathrm{~b}^{*}\right)$ of raw cooked meat products. In the evaluation of the individual sensory quality indicators after addition natural antioxidants we did not record statistically significant differences $(\mathrm{P}>0.05)$ between individual groups, indicating that the sensory quality of raw cooked meat products was not negatively affected by their addition. The fortification of meat-fatty batters using $100 \%$ bio juice and bio oil Sea buckthorn berries strongly inhibit lipid oxidation during storage and that suggest that it can be used as a natural preservative instead of chemical food additives.
\end{abstract}

Keywords: meat product, sea buckthorn, oxidative stability, colour, sensory

\section{INTRODUCTION}

Oxidation of the lipid component of food constitutes a serious problem in the food industry, as it leads to shorter durability, deterioration of taste, functional and nutritional properties of food products (Karre et al., 2013).

The loss of organoleptic properties is caused by the formation of undesirable substances, which occur mainly in the degradation of unsaturated fatty acids during autooxidation. Fats and oils are a component of almost all agri-food raw materials and a dominant component in many food products. All foods, even with low lipid content, are very susceptible to oxidative damage by active forms of air oxygen, especially when exposed to light (Schmidt, 2011).

Lipid oxidation during processing and storage of food is of great importance. Oxidation of unsaturated fatty acids produces hydroperoxides that are susceptible to further oxidation or decomposition into secondary reaction products such as hydrocarbons, alcohols, aldehydes, ketones, esters, and other oxygen-containing compounds that may adversely affect the overall food quality.

In meat and meat products, autooxidation is a key mechanism for lipid oxidation. Autooxidation is the oxidative degradation of unsaturated fatty acids by an autocatalytic process based on the mechanism of radical chain reactions. Chain radical oxidation generally occurs in a three-phase process, including the initiation, propagation, and termination phases. In particular, propagation reactions are responsible for the autocatalytic character of autooxidation (Hu and Jacobsen, 2016; Moudache et al., 2017).

Lund et al. (2011) reported that reduced oxidative stability also affects meat proteins. Protein oxidation has a negative impact on the nutritional and sensory properties of meat due to the oxidation of essential amino acids, their reduced usability and digestibility. It is imperative to slow down these oxidation processes because high-quality and durable foods that are not only safe but also beneficial to health are the interests of consumers and whole society (Jiang and Xiong, 2016; Chakanya et al., 2017).

Jung et al. (2013) states that lipid oxidation in foods is usually detected by measuring the concentration of malondialdehyde (MDA) because MDA is a rich secondary product of lipid oxidation and relatively stable compared to primary lipid oxidation products - hydroperoxides, which readily decompose into other oxidation products.

MDA is formed as a major product of the unsaturated fatty acid oxidation having three or more double bonds (Korchazhkina et al., 2003). Mendes et al. (2009) and Ansarin et al. (2017) report that MDA is one of the most important oxidation products believed to be a rodent carcinogen and a mutagen for mammalian cells. It is often used as a biomarker of oxidative damage in biological samples and food.

The most commonly used spectrophotometric method for measuring lipid oxidation in food and biological systems is the relatively fast, inexpensive and affordable thiobarbitur test, which generally uses 2-thiobarbituric acid (TBA), which can react with carbonyl compounds (Wang et al., 2002; Mendes et al., 2009; Ansarin et al., 2017).

Several factors have been used to slow or inhibit food self-oxidation (Takácsová and Paveleková, 2006; Schmidt, 2011; Ryu et al., 2014), with the addition of antioxidants being the most common and most preferred. Antioxidants have the potential to inhibit the oxidative degradation of the lipid component of the food and are also important for the protection of living cells from oxidative damage (Zeb and Ullah, 2015).

Antioxidants slow or inhibit the oxidation of other substances at low concentrations by preventing the initiation of oxidative chain reactions (Velasco and Williams, 2011; Gravador et al., 2015). 
The use of natural preservatives to control and restrict lipid oxidation, thereby to increase the shelf life of food products, is a promising technology also in meat industry and so far, its use is the least controversy from the consumer's point of view. Plant raw materials are readily available source of natural substances which may exhibit antioxidant and/or antimicrobial properties and the same raise the quality and sustainability of food products (Jo et al., 2013). Berries of Sea buckthorn (Hippophae rhamnoides L.) are perfect source of bioactive compounds. Fruits of this shrub are rich in polyphenols and vitamin, also contain large amounts of quercetine and flavonols in various forms (Rösch et al., 2003; Guliyev et al., 2014). As a nutraceutics are used in the treatment of skin changes subsequent radiation, burns, oral inflammation and gastric ulcers. Positive impact on human health may result by reducing the level of cholesterol in the blood plasma, inhibition of platelets aggregation process and regulation of immune function (Khan et al., 2010; Ma et al., 2019; Shkolnikova et al., 2019).

Despite the observed pro-health properties, very little data is available concerning the application of Sea buckthorn berries in raw cooked meat products. The objective of this study was to evaluate the effect of Hippophae rhamnoides L. on some quality properties of raw cooked meat products. Using the results obtained for the evaluated parameters, we aimed to assess the possibility to replace chemical food additives by used preparations.

\section{MATERIAL AND METHODS}

\section{Material}

The bio juice (100\%) and bio oil (100\%) of Sea Buckthorn Berries (Hippophae rhamnoides L.) were obtained from its producer PD Tvrdošovce. The bio oil is cold pressed, from hand-picked fruits, without chemical treatment and admixture, and bio sea buckthorn juice is cold-pressed from hand-picked plants with high oil content. Nutritional values in $100 \mathrm{ml}$ of the product are shown in Table. 1 .
Table 1 Nutritional values bio juice (100\%) and bio oil (100\%) in $100 \mathrm{~m}$ product (g)

\begin{tabular}{lcc}
\hline Composition & $\mathbf{1 0 0 \%}$ bio juice & $\mathbf{1 0 0 \%}$ bio oil \\
\hline Energy kJ & 260 & 3698 \\
Fat & 4.25 & 100 \\
Saturated fatty acids & 1.53 & 11.59 \\
Monosaturated fatty acids & - & 19.79 \\
Polysaturated fatty acids & - & 68.62 \\
Carbohydrates & 5.25 & 0 \\
Fibre & 0.64 & 0 \\
Protein & 0.96 & 0.43 \\
Vitamin E (mg) & - & 153 \\
Omega 3 fatty acids & - & 35 \\
Omega 6 fatty acids & - & 33 \\
Myristic acid & - & 0.49 \\
Palmitic acid & - & 7.23 \\
\hline
\end{tabular}

Raw cooked meat product was prepared from pork and backfat with addition of curing salt, water in the form of scaled ice and spices (Table 2). The control group was made without the addition of sea buckthorn oil or sea buckthorn juice. We added oil or juice to the remaining four groups at the following concentrations:

1. experimental group (P1) $-5 \mathrm{ml}$ of sea buckthorn juice per $\mathrm{kg}$ of meat mixture,

2. experimental group (P2) $-10 \mathrm{ml}$ of sea buckthorn juice per $\mathrm{kg}$ of meat mixture,

3. experimental group (P3) $-0.1 \mathrm{ml}$ of sea buckthorn oil per $\mathrm{kg}$ of meat mixture, 4. experimental group (P4) $-0.5 \mathrm{ml}$ of sea buckthorn oil per $\mathrm{kg}$ of meat mixture.

The samples were stored under refrigerated conditions at $4 \pm 1{ }^{\circ} \mathrm{C}$ for 10 days. Laboratory examinations of samples were performed on days $1,4,7$ and 10 of storage.

Table 2 Formula of meat batters $\left(\mathrm{g} \cdot \mathrm{kg}^{-1}\right)$

\begin{tabular}{|c|c|c|c|c|c|c|c|c|}
\hline & Pork & Backfat & $\begin{array}{c}\text { Curing } \\
\text { salt }\end{array}$ & $\begin{array}{c}\text { Ice } \\
\text { water }\end{array}$ & Diphosphate & $\begin{array}{c}\text { Red } \\
\text { Pepper }\end{array}$ & $\begin{array}{c}100 \% \text { bio oil } \\
(\mathrm{ml})\end{array}$ & $\begin{array}{l}100 \% \text { bio } \\
\text { juice (ml) }\end{array}$ \\
\hline C & 600 & 250 & 18 & 200 & 0.07 & 7 & - & - \\
\hline P1 & 600 & 250 & 18 & 200 & 0.07 & 7 & 0.1 & - \\
\hline P2 & 600 & 250 & 18 & 200 & 0.07 & 7 & 0.5 & - \\
\hline P3 & 600 & 250 & 18 & 200 & 0.07 & 7 & - & 5 \\
\hline P4 & 600 & 250 & 18 & 200 & 0.07 & 7 & - & 10 \\
\hline
\end{tabular}

\section{Lipid Oxidation}

Determination of the lipid oxidation during four storage times (day 1, 4, 7 and 10), oxidative stability of meat product samples was determined according to Marcinčák et al. (2010). The method is based on the rupture of lipid bilayer by free radical to form malondialdehyde (MDA) as a secondary product. Two molecules of thiobarbituric acid react with one molecule of MDA to form pink coloured product showing maximum absorbance at $532 \mathrm{~nm}$ called TBARS. The absorbance was measured using UV spectrophotometer (Jenway UV-VIS Spectrophotometer). The results were calculated as malondialdehyde (MDA) quantity per $1 \mathrm{~kg}$ of sample.

\section{Colour Determination}

The colour of raw cooked meat products was evaluated using a reflectance colorimeter Konica Minolta CM-2600d and it was expressed in scale $\mathrm{L}^{*}$ (lightness) $\mathrm{a}^{*}$ (redness) $\mathrm{b}^{*}$ (yellowness) in CIE Lab system. Before each measuring session the instrument was calibrated against white reference. The evaluation was conducted on days $1,4,7$ and 10 of cold storage.

\section{Sensory evaluation}

Sensory quality of raw-cooked meat products after cooking $\left(80{ }^{\circ} \mathrm{C}, 5 \mathrm{~min}\right.$.) was assessed by six-member panel on the $4^{\text {th }}$ day after processing. Sensory characteristics of meat products including surface appearance and colour, appearance and colour in cross-section, texture, aroma, and taste on a five-point hedonic scale $(6=$ very good, $1=$ very bad $)$.

\section{Statistical analysis}

The data were subjected to statistical analysis using the Statistic Analysis System (SAS) package (SAS 9.3 using of application Enterprise Guide 4.2) by nonparametric Wilcoxon test.

\section{RESULTS AND DISCUSSION}

The level of oxidative damage of lipids in the manufacture and storage of rawcooked meat products is presented in Table 3. As regards determination of oxidative stability on day 1 , the highest MDA content was found in control group $\left(0.239 \mathrm{mg} \cdot \mathrm{kg}^{-1}\right)$ compared to all experimental groups (from $0.199 \mathrm{mg} \cdot \mathrm{kg}^{-1}-\mathrm{P} 4$ to $\left.0.214 \mathrm{mg} \cdot \mathrm{kg}^{-1}-\mathrm{P} 3\right)$, but we have found significantly differences $(\mathrm{P} \leq 0.05)$ only between control and experimental group P4. At the end of storage (day 10), we observed higher oxidation stability $(\mathrm{P} \leq 0.05)$ in all experimental groups with Sea Buckthorn berries supplements and therefore a lower MDA value compared to the control group without the addition of juice and oil. In control group was recorded the highest production of MDA $\left(0.289 \mathrm{mg} \cdot \mathrm{kg}^{-1}\right)$. From the experimenta groups with different additions $(\mathrm{P} \geq 0.05)$ of bio juice and oil, we observed the highest degree of oxidative stability in the experimental group $\mathrm{P} 4$ with addition of bio oil in the amount of $0.5 \mathrm{ml}\left(0.229 \mathrm{mg} \cdot \mathrm{kg}^{-1}\right)$ and bio juice with addition of $10 \mathrm{ml}\left(\mathrm{P} 2-0.234 \mathrm{mg} \cdot \mathrm{kg}^{-1}\right)$.

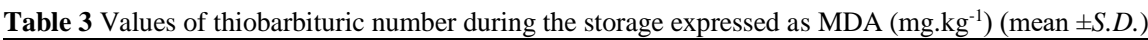

\begin{tabular}{lllllll}
\hline & C & P1 & P2 & P3 & P4 \\
\hline Day 1 & $0.239 \pm 0.024^{\mathrm{b}}$ & $0.213 \pm 0.002^{\mathrm{ab}}$ & $0.206 \pm 0.006^{\mathrm{ab}}$ & $0.214 \pm 0.012^{\mathrm{ab}}$ & $0.199 \pm 0.010^{\mathrm{a}}$ & 0.040 \\
Day 4 & $0.259 \pm 0.010^{\mathrm{b}}$ & $0.222 \pm 0.006^{\mathrm{a}}$ & $0.216 \pm 0.005^{\mathrm{a}}$ & $0.228 \pm 0.015^{\mathrm{a}}$ & $0.207 \pm 0.014^{\mathrm{a}}$ & 0.017 \\
Day 7 & $0.284 \pm 0.011^{\mathrm{b}}$ & $0.243 \pm 0.018^{\mathrm{a}}$ & $0.228 \pm 0.020^{\mathrm{a}}$ & $0.240 \pm 0.016^{\mathrm{a}}$ & $0.226 \pm 0.009^{\mathrm{a}}$ & 0.016 \\
Day 10 & $0.289 \pm 0.013^{\mathrm{b}}$ & $0.248 \pm 0.015^{\mathrm{a}}$ & $0.234 \pm 0.011^{\mathrm{a}}$ & $0.245 \pm 0.019^{\mathrm{a}}$ & $0.229 \pm 0.017^{\mathrm{a}}$ & 0.017 \\
\hline
\end{tabular}

Note: MDA - malondialdehyde; C - control group; P1, P2, P3, P4 - experimental groups; a, b in the same row means significant differences $(\mathrm{P}<0.05)$.

A slightly higher degree of oxidative damage was observed with the addition of bio oil in the amount of $0.1 \mathrm{ml}\left(\mathrm{P} 3-0.245 \mathrm{mg} \cdot \mathrm{kg}^{-1}\right)$ and bio juice with the addition of $5 \mathrm{ml}\left(\mathrm{P} 1-0.248 \mathrm{mg} \cdot \mathrm{kg}^{-1}\right)$. The results of oxidative stability achieved by raw cooked meat products show a higher level of oxidative stability after application of natural antioxidant in the form of bio oil and bio juice. This fact is in accordance with the findings of Salejda et al. (2014), Armenteros et al. (2016) and Zahid et al. (2018), who also noted increased oxidative stability of meat products after application of natural antioxidants 
Table 4 CIE colour values of meat products at different time of measurement (mean)

\begin{tabular}{|c|c|c|c|c|c|c|c|c|c|c|c|c|}
\hline \multirow[b]{2}{*}{ Group/day } & \multicolumn{4}{|c|}{$\mathbf{L}^{*}$} & \multicolumn{4}{|c|}{$\mathbf{a}^{*}$} & \multicolumn{4}{|c|}{$\mathbf{b}^{*}$} \\
\hline & 1 & 4 & 7 & 10 & 1 & 4 & 7 & 10 & 1 & 4 & 7 & 10 \\
\hline $\mathbf{C}$ & 57.68 & 56.39 & 53.79 & 48.43 & 24.58 & 25.90 & 27.59 & 30.09 & 34.94 & 35.42 & 35.38 & 35.30 \\
\hline P1 & 55.33 & 53.81 & 51.27 & 45.64 & 24.70 & 26.26 & 28.80 & 30.52 & 32.66 & 35.83 & 37.06 & 39.03 \\
\hline $\mathbf{P 2}$ & 55.29 & 54.63 & 51.92 & 45.70 & 24.38 & 26.30 & 28.64 & 30.30 & 32.73 & 35.39 & 36.12 & 37.12 \\
\hline P3 & 59.47 & 55.77 & 53.13 & 47.16 & 24.64 & 25.86 & 27.68 & 29.62 & 33.34 & 35.63 & 35.57 & 35.52 \\
\hline P4 & 57.21 & 56.16 & 49.84 & 46.48 & 24.65 & 27.05 & 28.50 & 29.50 & 32.69 & 38.27 & 36.07 & 34.57 \\
\hline
\end{tabular}

Note: C - control group; P1, P2, P3, P4 - experimental groups.

The lightness ( $\mathrm{L}^{*}$ parameter) in raw cooked meat product was affected by the addition of Sea Buckthorn Berries as shown in the table 4. The use of the experimental preparation reduced the lightness $(\mathrm{P}>0.05)$ of the meat product from 57.68 in the control group to 55.33 (P1), respectively 55.29 (P2) with the addition of $100 \%$ bio juice. When using the experimental groups with the addition of $100 \%$ bio oil, we did not notice the effect $(\mathrm{P}>0.05)$ on the lightness of the meat product compared to the control group. The shelf life of meat products in all groups resulted in a decrease in the endpoint. When evaluating the intensity of red colour $\left(\mathrm{a}^{*}\right.$ parameter), we noticed differences $(\mathrm{P}>0.05)$ in the given indicator between individual experimental groups. By storing meat products, we have seen the opposite tendency of this parameter, is its increase during the whole storage period. The results of this study, when evaluating parameter $b^{*}$, point to an increase in its value $(\mathrm{P}>0.05)$ during storage in all samples of meat products, thus increasing the participation of yellow colour in colour space. Decrease of $\mathrm{L}^{*}$ colour parameter after addition to meat products preparations of plant origin also observed (Fernendez - Lopez et al., 2005; Salejda et al., 2011; Salejda et al., 2014) in products produced with rosemary extract, green tea extract and Sea Buckthorn Berries extract.

Table 5 Sensory evaluation (point) of raw cooked meat products (mean \pm S.D.)

\begin{tabular}{lccccc}
\hline Sensory characteristics & C & P1 & $\begin{array}{c}\text { Group } \\
\text { P2 }\end{array}$ & P3 & P-value \\
\hline $\begin{array}{l}\text { Surface appearance } \\
\text { and colour }\end{array}$ & $5.17 \pm 0.55$ & $5.00 \pm 0.50$ & $4.92 \pm 0.61$ & $5.08 \pm 0.45$ & $5.00 \pm 0.29$ \\
$\begin{array}{l}\text { Appearance and colour } \\
\text { in cross-section }\end{array}$ & $5.42 \pm 0.45$ & $5.33 \pm 0.37$ & $5.50 \pm 0.50$ & $5.42 \pm 0.61$ & $5.42 \pm 0.53$ \\
Texture & $5.33 \pm 0.37$ & $5.25 \pm 0.48$ & $5.50 \pm 0.50$ & $5.25 \pm 0.48$ & $5.33 \pm 0.33$ \\
Aroma & $5.50 \pm 0.41$ & $5.50 \pm 0.41$ & $5.58 \pm 0.45$ & $5.30 \pm 0.55$ & $5.42 \pm 0.53$ \\
Taste & $5.50 \pm 0.41$ & $5.33 \pm 0.37$ & $5.25 \pm 0.38$ & $5.50 \pm 0.41$ & 0.571 \\
\hline Note: C - control group; P1, P2, P3, P4 - experimental groups & & & & \\
\end{tabular}

The mean value of sensory characteristics of raw cooked meat products (surface appearance and colour, appearance and colour in cross-section, texture, aroma and taste) after addition of natural antioxidant (Sea Buckthorn Berries - juice and oil) are presented in Table 5 . In the evaluation of the individual sensory quality indicators after addition natural antioxidants we did not record statistically significant differences $(\mathrm{P}>0.05)$ between individual groups, indicating that the sensory quality of raw cooked meat products was not negatively affected by their addition. In the evaluation of the most important indicator of sensory quality (taste) we recorded similar ratings in all experimental groups with the addition of natural antioxidant than in the control group. Similar results were found in study of Mohamend and Mansour (2012) who investigated oregano and rosemary extract in beef patties, as well as Kulkarni et al. (2011) who investigated grape seed in beef sausages and Boruzi and Nour (2019) who investigated walnut leaf extract with no significant effects on sensory quality.

\section{CONCLUSION}

Based on the results obtained using the addition of Sea buckthorn berries (Hippophae rhamnoides L.) in the production of raw cooked meat products, it can be stated that it is a suitable functional ingredient that can be used to increase the quality of meat products. The fortification of meat-fatty batters using $100 \%$ bio juice and bio oil Sea buckthorn berries strongly inhibit lipid oxidation during storage and that suggest that it can be used as a natural preservative instead of chemical food additives.

Acknowledgments: This work was supported by grants KEGA No. 025SPU4/2019, APVV-17-0508 and APVV-18-0312.

\section{REFERENCES}

Ansarin, K., Khoubnasabjafari, M., \& Jouyban, A. (2017). Reliability of malondialdehyde as a biomarker of oxidative stress in psychological disorders. BioImpacts, 5(3), 123-127. https://doi.org/10.15171/bi.2015.20

Armenteros, M., Morcuende, D., Ventanas, J., \& Estévez, M. (2016). The application of natural antioxidants via brine injection rotects Iberian cooked hams against lipid and protein oxidation. Meat Science, 116, 253-259. https://doi.org/10.1016/j.meatsci.2016.02.027

Boruzi, A. I., \& Nour, V. (2019). Antioxidant Effects of Walnut Leaves and Sweet Cherry Stems on Color, Lipid Oxidation and Sensory Quality of Cooked Pork Patties. Notulae Botanicae Horti Agrobotanici Cluj-Napoca, 47(3) https://doi:10.15835/nbha47311458

Fernández-López, J., Zhi, N., Aleson-Carbonell, L., Pérez-Alvarez, J. A., \& Kuri, V. (2005). Antioxidant and antibacterial activities of natural extracts: application in beef meatballs. Meat Science, 69(3), 371-380. https://doi.org/10.1016/j.meatsci.2004.08.004

Gravador, R. S., Luciano, G., Jongberg, S., Bognanno, M., Scerra, M., Andersen, M. L., Lund, M. N., \& Priolo, A. (2015). Fatty acids and oxidative stability of meat from lambs fed carob-containing diets. Food Chemistry, 82, 27-34. https://doi.org/10.1016/j.foodchem.2015.02.094

Guliyev, V., Gul, M., \& Yildirim, A. (2004). Hippophae rhamnoides L. chromatographic methods to determine chemical composition, use in traditional medicine and pharmacological effects. Journal of Chromatography B, 812(1-2), 291-307. https://doi.org/10.1016/s1570-0232(04)00720-2

$\mathrm{Hu}$, M., \& Jacobsen, Ch. (2016). Oxidative Stability and Shelf Life of Foods Containing Oils and Fats. Illinois: AOCS Press. 519. ISBN 978-1-63067-056-6. https://doi.org/10.1016/c2015-0-00077-6

Chakanya, Ch., Arnaud, E., Muchenje, V., \& Hoffman, L. C. (2017). Colour and oxidative stability of mince produced from fresh and frozen/thawed fallow deer (Dama dama) meat. Meat Science, 126, 63-72. https://doi.org/10.1016/j.meatsci.2016.12.008

Jiang, J., \& Xiong, Y. L. (2016). Natural antioxidants as food and feed additives to promote health benefits and quality of meat products: A review. Meat Science 120, 107-117. https://doi.org/10.1016/j.meatsci.2016.04.005

Jo, C., Son, J. H., Son, C. B., \& Byun, M. W. (2003). Functional properties of raw and cooked pork patties with added irradiated, freeze-dried green tea leaf extract powder during storage at $4{ }^{\circ} \mathrm{C}$. Meat Science, 64(1), 13-17. https://doi.org/10.1016/s0309-1740(02)00131-6

Jung, S., Ki, C. N., Ahn, D. U., Kim, H. J., \& Jo, Ch. (2013). Effect of phosvitin on lipid and protein oxidation in ground beef treated with high hydrostatic $\begin{array}{llll}\text { pressure. } & \text { Meat } & \text { science, } & \text { 95(1), }\end{array}$ https://doi.org/10.1016/j.meatsci.2013.04.005

Karre, L., Lopez, K., \& Getty, K. J. K. (2013). Natural antioxidants in meat and $\begin{array}{llll}\text { poultry } \quad \text { Meat } & \text { Science, } & \text { 94(2), } 227 .\end{array}$ https://doi.org/10.1016/j.meatsci.2013.01.007

Khan, B. A., Akhtar, N., \& Mahmood, T. (2010). A Comprehensive Review of a Magic Plant, Hippophae rhamnoides. Pharmacognosy Journal, 2(16), 65-68. https://doi.org/10.1016/s0975-3575(10)80053-7

Korchazhkina, O., Exley, C., \& Spencer, S. A. (2003). Measurement by reversedphase high-performance liquid chromatography of malondialdehyde in norma human urine following derivatisation with 2,4-dinitrophenylhydrazine. Journal of Chromatography B, 794(2), 353-362. https://doi.org/10.1016/s15700232(03)00495-1

Kulkarni, S., Desantos, F. A., Kattamuri, S., Rossi, S. J., \& Brewer, M. S. (2011) Effect of grape seed extract on oxidative, color and sensory stability of a precooked, frozen, re-heated beef sausage model system. Meat Science, 88(1), 139144. https://doi.org/10.1016/j.meatsci.2010.12.014

Lund, M. N., Heinonen, M., Baron, C. P., \& Estévez, M. (2011). Protein oxidation in muscle foods: A review. Molecular Nutrition \& Food Research 55(1), 83-95. https://doi.org/10.1002/mnfr.201000453

Ma, X., Moilanen, J., Laaksonen, O., Yang, W., Tenhu, E., \& Yang, B. (2019). Phenolic compounds and antioxidant activities of tea-type infusions processed from sea buckthorn (Hippophaë rhamnoides) leaves. Food Chemistry, 272, 1-11. https://doi.org/10.1016/j.foodchem.2018.08.006 
Marcinčák, S., Popelka, P., Šimková, J., Marcinčáková, D., \& Martonová, M. (2010). Oxidative stability of chilled chicken meat after feeding of selected plants. Potravinarstvo, 4(3), 46-49. http://dx.doi.org/10.5219/

Mendes, R., Cardoso, C., \& Pestena, C. (2009). Measurement of malondialdehyde in fish: A comparison study between HPLC methods and the traditional spectrophotometric test. Food Chemistry, 112(4), 1038-1045. https://doi.org/10.1016/j.foodchem.2008.06.052

Mohamed, H. M. H., \& Mansour, H. A. (2012). Incorporating essential oils of marjoram and rosemary in the formulation of beef patties manufactured with mechanically deboned poultry meat to improve the lipid stability and sensory attributes. LWT - Food Science and Technology, 45(1), 79-87. http://doi:10.1016/j.lwt.2011.07.031

Moudache, M., Nerín, C., Colon, M., \& Zaidi, F. (2017). Antioxidant effect of an innovative active plastic film containing olive leaves extract on fresh pork meat and its evaluation by Raman spectroscopy. Food Chemistry, 229, 98-103. https://doi.org/10.1016/j.foodchem.2017.02.023

Rösch, D., Bergmann, M., Knorr, D., \& Kroh, L.W. (2003). Structure-Antioxidant Efficiency Relationships of Phenolic Compounds and Their Contribution to the Antioxidant Activity of Sea Buckthorn Juice. Journal of Agricultural and Food Chemistry, 51 (15), 4233-4239. https://doi.org/10.1021/jf0300339

Ryu, K. S., Shim, K. S., \& Shin, D. (2014). Effect of grape pomace powder addition on TBARS and colour of cooked pork sausages during storage. Korean Journal for Food Science of Animal Resources, 34(2), 200-206. https://doi.org/10.5851/kosfa.2014.34.2.200

Shkolnikova, M., Shkolnikova, M., Rozhnov, E., Rozhnov, E., Pryadikhina, A., \& Pryadikhina, A. (2019). Effects of Granucol activated carbons on sensory properties of sea-buckthorn (Hippophae rhamnoides L.) wines. Foods and Raw Materials, 7(1), 67-73. https://doi.org/10.21603/2308-4057-2019-1-67-73

Salejda, A. M., Krasnowska, G. \& Tril, U. (2011). „Attempt to utilize antioxidant properties of green tea extract in the production of model meat products". Żywność. Nauka. Technologia. Jakość, $5(78), 107 \quad-118$ https://doi.org/10.15193/zntj/2011/78/107-118

Salejda, A. M., Tril, U., \& Krasnowska, G. (2014). 'The Effect of Sea Buckthorn (Hippophae rhamnoides L.) Berries on Some Quality Characteristics of Cooked Pork Sausages'. World Academy of Science, Engineering and Technology, International Journal of Nutrition and Food Engineering, 8(6), 604 - 607. https://doi.org/10.5281/zenodo.1093382

SAS (2008) 9.3 Enhanced Logging Facilities, Cary, NC: SAS Institute Inc., 2008. Schmidt, S. (2011). Antioxidanty a oxidačné zmeny tukov v potravinách Bratislava: Nakladatel'stvo STU. 220 s. ISBN 978-80-227-3491-2.

Takácsová, M., \& Paveleková, I. (2006). Chemická a biologická bezpečnost potravín a analýza potravín. In HELD, L. Teória a prax výchovy $k$ zdravej výźive $v$ školách. Bratislava: TU, VEDA, 281-323. ISBN 80-8082-077-5.

Velasco, V., \& Williams, P. (2011). Improving meat quality through natural antioxidants. Chilean journal of agricultural research, 71(2), 313-322. https://doi.org/10.4067/s0718-58392011000200017

Wang, B., Pace, R. D., Dessai, A. P., Bovell-Benjamin, A., \& Phillips, B. (2002). Modified extraction method for determining 2-thibarbituric acid values in meat with increased specificity and simplicity. Food Chemistry and Toxicology, 67(8), 2833-2836. https://doi.org/10.1111/j.1365-2621.2002.tb08824.x

Zahid, A., Seo, J. K., Park, J. Y., Jeong, J. Y., Jin, S. K., Park, T. S., \& Yang, H. S. (2018). The Effects of Natural Antioxidants on Protein Oxidation, Lipid Oxidation, Color, and Sensory Attributes of Beef Patties during Cold Storage at $4^{\circ} \mathrm{C}$. Korean Journal for Food Science of Animal Resources, 38(5), 1029-1042. https://doi:10.5851/kosfa.2018.e36

Zeb, A., \& Ullah, S. (2015). Sea buckthorn seed oil protects against the oxidative stress produced by thermally oxidized lipids. Food Chemistry, 186, 6-12. https://doi.org/10.1016/j.foodchem.2015.03.053 